\title{
Soil carbon, nitrogen and phosphorus ecological stoichiometry shifts with tree species in subalpine plantations
}

\author{
Kai bin $\mathbf{Q i}^{1,2}$, Xueyong Pang ${ }^{1}$, Bing Yang ${ }^{1}$, Weikai Bao ${ }^{\text {Corresp. } 1}$ \\ ${ }^{1}$ CAS Key Laboratory of Mountain Ecological Restoration and Bioresource Utilization \& Ecological Restoration Biodiversity Conservation Key Laboratory of \\ Sichuan Province, Chengdu Institute of Biology, Chinese Academy of Sciences, Chengdu, China \\ 2 University of Chinese Academy of Sciences, Beijing, China \\ Corresponding Author: Weikai Bao \\ Email address: baowk@cib.ac.cn
}

Understanding ecological stoichiometric characteristics of soil nutrient elements, such as carbon $(C)$, nitrogen $(N)$ and phosphorus $(P)$ is crucial to guide ecological restoration of plantations in ecologically vulnerable areas, such as alpine and subalpine regions. However, there has been only a few related studies, and thus whether and how different tree species would affect soil C:N:P ecological stoichiometry remains unclear. We compared soil C:N:P ecological stoichiometry of Pinus tabulaeformis, Larix kaempferi and Cercidiphyllum japonicum to primary shrubland in a subalpine region. We observed strong tree-specific and depth-dependent effects on soil C:N:P stoichiometry in subalpine plantations. In general, the C:N, C:P and N:P of topsoil $(0-10 \mathrm{~cm})$ are higher than subsoil $(>10 \mathrm{~cm}$ ) layer at 0-30 $\mathrm{cm}$ depth profiles. The differences in C:N, N:P and C:P at the topsoil across target tree species were significantly linked to standing litter stock, tree biomass/total aboveground biomass and Margalef's index of plant community, respectively, whereas the observed variations of $\mathrm{C}: \mathrm{N}, \mathrm{N}: \mathrm{P}$ and $\mathrm{C}: \mathrm{P}$ ratio among soil profiles are closely related to differences in soil bulk density, soil moisture, the quantity and quality of aboveground litter inputs as well as underground fine root across plantations examined. Our results highlight that soil nutrients in plantation depend on litter quantity and quality of selected tree species as well as soil physical attributes. Therefore, matching site with trees is crucial to enhance ecological functioning in degraded regions resulting from human activity. 
1 Soil carbon, nitrogen and phosphorus ecological stoichiometry shifts with tree

\section{2 species in subalpine plantations}

3 Kaibin Qi ${ }^{1,2}$, Xueyong Pang ${ }^{1}$, Bing Yang ${ }^{1}$, Weikai Bao ${ }^{1 *}$

$4{ }^{1}$ CAS Key Laboratory of Mountain Ecological Restoration and Bioresource Utilization \&

5 Ecological Restoration Biodiversity Conservation Key Laboratory of Sichuan Province,

6 Chengdu Institute of Biology, Chinese Academy of Sciences, P.O. Box 416, Chengdu 610041,

7 China

$8{ }^{2}$ University of Chinese Academy of Sciences, Beijing 100049, China

10 Corresponding Author: Weikai Bao

11 Address: Chengdu Institute of Biology, Chinese Academy of Sciences, P.O. Box 416, Chengdu

12 610041, P. R. China;

13 Email: baowk@cib.ac.cn (W.K. Bao). Tel: +86-28-82890528; Fax: +86-28-82890288). 
21 Abstract

Understanding ecological stoichiometric characteristics of soil nutrient elements, such as carbon (C), nitrogen $(\mathrm{N})$ and phosphorus $(\mathrm{P})$ is crucial to guide ecological restoration of plantations in ecologically vulnerable areas, such as alpine and subalpine regions. However, there has been only a few related studies, and thus whether and how different tree species would affect soil C:N:P ecological stoichiometry remains unclear. We compared soil C:N:P ecological stoichiometry of Pinus tabulaeformis, Larix kaempferi and Cercidiphyllum japonicum to primary shrubland in a subalpine region. We observed strong tree-specific and depth-dependent effects on soil C:N:P stoichiometry in subalpine plantations. In general, the $\mathrm{C}: \mathrm{N}, \mathrm{C}: \mathrm{P}$ and $\mathrm{N}: \mathrm{P}$ of topsoil $(0-10 \mathrm{~cm})$ are higher than subsoil (>10 cm) layer at 0-30 cm depth profiles. The differences in C:N, N:P and C:P at the topsoil across target tree species were significantly linked to standing litter stock, tree biomass/total aboveground biomass and Margalef's index of plant community, respectively, whereas the observed variations of $\mathrm{C}: \mathrm{N}, \mathrm{N}: \mathrm{P}$ and $\mathrm{C}: \mathrm{P}$ ratio among soil profiles are closely related to differences in soil bulk density, soil moisture, the quantity and quality of aboveground litter inputs as well as underground fine root across plantations examined. Our results highlight that soil nutrients in plantation depend on litter quantity and quality of selected tree species as well as soil physical attributes. Therefore, matching site with trees is crucial to enhance ecological functioning in degraded regions resulting from human activity.

Key words: ecological stoichiometry; plantation in subalpine region; soil depth; litter; fine root.

\section{Introduction}

Ecological stoichiometry addresses the equilibrium or interactions of the main elements as well as the correlations between elements and ecosystem functioning (Cambardella \& Elliott 1992; Elser 2000; Gusewell 2004). Nitrogen (N) and Phosphorus (P) are the most critical nutrients limiting plant growth, and their balance can regulate biological processes in terrestrial ecosystems (Elser et al. 2007; Gusewell 2004; Reich \& Oleksyn 2004; Vitousek \& Howarth 1991), such as the process of carbon (C) storage (Hessen et al. 2004; Yu et al. 2015). Soil C:N, a sensitive indicator of the $\mathrm{C}$ and $\mathrm{N}$ reserves and also a soil quality in ecosystems (Tessier \& Raynal 2003), is bound up with the $\mathrm{C}$ allocation and $\mathrm{N}$ mineralization rates of soil organic material in forest ecosystems. Soil C:P reflects the ability of soil $\mathrm{P}$ mineralization, a low soil $\mathrm{C}: \mathrm{P}$ favors microorganisms to decompose organic matter and desorb nutrients, thus provides higher soil available $P$ content (Tian et al. 2010). Soil N:P can measure the $\mathrm{N}$ saturation status and it is used to determine the thresholds for soil nutrient limitation (Tessier \& Raynal 2003). The biogeochemical cycles of C, N, and P in terrestrial ecosystems are strongly interconnected through the biochemical reactions during primary production, respiration and decomposition (Daufresne \& Loreau 2001; Zechmeister- 
Boltenstern et al. 2015). A deficiency or lower content of $\mathrm{N}$ and $\mathrm{P}$ leads to a higher C:N and C:P ratios, and their excess triggers C deficiency (Gusewell et al. 2005; Tessier \& Raynal 2003).

Since the C:N:P stoichiometry is regarded as an indicator of soil fertility and the excess/limitation conditions of soil nutrients (Bing et al. 2016), studying its response to disturbance resulting from human activities is essential for the enhancing of ecosystem functioning. Although some studies report that soil C:N:P ecological stoichiometric ratios are well-constrained (Cleveland \& Liptzin 2007), others found that soil C:N:P stoichiometric ratios can be affected by climate factors including temperature and precipitation (Callesen et al. 2007; Vesterdal et al. 2008; Zhang et al. 2019b), topography factors, such as elevation and latitude (Moser et al. 2011; Whitaker et al. 2014; $\mathrm{Xu}$ et al. 2013; Zhang et al. 2019b), soil texture and vegetation types (Cools et al. 2014; Feng et al. 2017; Tian et al. 2010; Vesterdal et al. 2008; Xu et al. 2013). In addition, ecological stoichiometry can also be influenced by ecological restoration approaches, and afforestation can be a major factor affecting soil C:N:P stoichiometric ratio (e.g., Davis et al. 2007; Deng et al. 2014). Different tree species planted for restoration of afforestation can influence soil properties through multiple pathways. However, in alpine and subalpine regions whether there are differences in soil $\mathrm{C}: \mathrm{N}: \mathrm{P}$ stoichiometric ratio between afforestation and reforestation remains largely unknown. Moreover, tree species differ from one another in the quality and quantity of litter and root exudate (Aponte et al. 2012; Paterson et al. 2007) and this in turn can influence soil C and $\mathrm{N}$ mineralization mediated by microbial communities (Alberti et al. 2015; Prescott \& Grayston 2013). Finally, the vertical patterns of C, N and P stoichiometry vary with ecosystem type (Feng et al. 2017). Although a few studies have examined soil $\mathrm{C}: \mathrm{N}: \mathrm{P}$ stoichiometric ratios of forest ecosystems in alpine and subalpine region (Bing et al. 2016; Feng \& Bao 2018; Feng et al. 2017; Mueller et al. 2017; Yang et al. 2014; Zhang et al. 2019b), studying how C:N:P stoichiometric ratios respond to ecological restoration in depth should include more tree species and more sites. The main objective of this study was to evaluate the effect of commonly used tree species in plantations on soil C:N:P ecological stoichiometry. Since soil stoichiometric ratios vary with the species characteristics of plantations (Lawrence et al. 2013; Sardans et al. 2012; Vinton \& Burke 1995), we hypothesized that: 1) the soil C:N:P stoichiometry of plantations would be influenced by the tree species; 2) the variations in soil C: N: P stoichiometric ratio across tree species decrease with increase in soil depth because the influence of litter input on soil nutrient decreases with increase in soil layer; 3 ) the fine root biomass (FRB), standing litter stock (LS), tree biomass/total aboveground biomass (TB/TAB) and Margalef's index are major influencing factors of soil C:N:P ecological stoichiometry, whereas the effect size depends on soil depth.

\section{Materials and methods}




\section{Study area}

The study was conducted at the Mao Country Mountain Ecosystem Research Station $\left(31^{\circ} 37^{\prime} \mathrm{N}\right.$, $103^{\circ} 54^{\prime}$ E), the Chinese Academy of Sciences, which located in Sichuan province, China. The mean monthly temperature of the study area ranges from $-0.9{ }^{\circ} \mathrm{C}$ in January to $18.6^{\circ} \mathrm{C}$ in July, with an annual mean temperature of $9.3^{\circ} \mathrm{C}$. The growing season is from May to September. The mean annual precipitation is approximately $900 \mathrm{~mm}$, about $70 \%$ falls during the growing season. The annual accumulated temperature, greater than or equal to $10^{\circ} \mathrm{C}$ is $2635.1{ }^{\circ} \mathrm{C}$. The soil at the study site belongs to a Calcic Luvisol according to the IUSS Working Group WRB (2007). The soil texture was silt loam with $15.5 \%$ and $15.3 \%$ of sand, $62.5 \%$ and $63.3 \%$ of silt, $21.9 \%$ and $21.5 \%$ of clay in the $0-10 \mathrm{~cm}$, and 10-20 cm soil depths, respectively (Jiang et al. 2011).

\section{Forest types and management activities}

In August 2007, plantations of Pinus tabulaeformis (PT), Larix kaempferi (LAR), Cercidiphyllum japonicum (CJ) from three different sites were selected and native secondary shrublands dominated by Corylus heterophylla and Quercus liaotungensis nearby were chosen as control, resulting in 12 woodlands. We chose PT, LAR and CJ because they were commonly used when restoring or replacing native thicket in western Sichuan province, as was also the case with the study area (Pang \& Bao 2011). These plantations were established with terracing in the spring of 1987 on cutovers of primary thicket, which were clear-fallen in the autumn of 1986 . They have not been fertilized since the establishment. Prior to establishment, the main soil properties in these plantations were similar to those of the native secondary coppice forest (Pang \& Bao 2011). In August 2018, we sampled these plots again to examine the changes during the past 11 years. The understory species were dominated by native broad-leaved species, including Quercus aliena, Corylus heterophylla, Rosa spp., Spiraea spp., Phlanis umbrosa, Voila spp., Anaphalis sinica, Potentilla spp., without any species being absolutely dominant (Pang \& Bao 2011). The other basic information about the chosen forests was shown in the Table 1.

\section{Vegetation measurements, soil sampling and analysis}

In August 2007 and 2018, three $10 \times 10 \mathrm{~m}$ standard plot was randomly set in an area of about 0.5 ha for each woodland. The height $(\mathrm{H})$ and the diameter at breast height $(\mathrm{DBH})$ of trees in each plot were measured and stand density were calculated.

In each plot, the aboveground biomass of each layer of understory vegetation (including shrubs and herbs) were recorded using destructive sampling in five $2 \mathrm{~m} \times 2 \mathrm{~m}$ quadrates. All aboveground biomass within each sampling category was clipped and dried at $65{ }^{\circ} \mathrm{C}$ until the weight was constant. The litter on the soil surface was collected from the same quadrates, mixed, dried at 65 ${ }^{\circ} \mathrm{C}$ and weighted. Soil samples were collected to a depth of $30 \mathrm{~cm}$ at three intervals of $0-10,10-$ 
12420 and 20-30 cm from 10 random sampling sites along a "W" shape with a soil auger (50 mm 125 diameter). These sampling sites were at least $1.5 \mathrm{~m}$ apart from each other and $2 \mathrm{~m}$ away from the 126 boundary. The samples from each quadrat were pooled to give one composite sample per plot and 127 depth. The soil samples were taken to the laboratory and soil moisture content were determined 128 with $20 \mathrm{~g}$ soil each sample in oven drying method at $105^{\circ} \mathrm{C}$ for $24 \mathrm{~h}$. The soil bulk density (BD) was determined using stainless steel cylinders $\left(100 \mathrm{~cm}^{3}\right)$ in triplicate for each plot before soil sampling ( $\mathrm{Qu}$ et al. 2016). The BD of soil was calculated by dividing the dry mass after oven drying at $105{ }^{\circ} \mathrm{C}$ for 24 hours of each composite soil sample by the sample volume. The soil samples were air-dried after removing the gravel, soil animals and plant debris and breaking the large fractions. The air-dried soil sample was ground and then passed through 20 -mesh $(0.9 \mathrm{~mm})$ and 100-mesh $(0.15 \mathrm{~mm})$ nylon sieves, respectively(Li et al. 2018). The processed samples were preserved for the determination of soil organic carbon (SOC), total nitrogen (TN) and total phosphorus (TP). SOC and TN were determined by combustion in a Macro Elemental Analyser (vario MACRO, Elementar Co., Germany). The TP was measured using the sulphuric acid-soluble perchlorate acid- molybdenum antimony colorimetric method (Bowman 1988). C, N, and P contents in leaves, litter, and soil samples were mass-based. The atomic ratios were determined according to the formula:

$\mathrm{C}: \mathrm{N}=\frac{\mathrm{C}_{\text {content }} / 12}{\mathrm{~N}_{\text {content } / 14}}$.

$142 \mathrm{~N}: \mathrm{P}=\frac{\mathrm{N}_{\text {content }} / 14}{\mathrm{P}_{\text {content }} / 31}$.

$\mathrm{C}: \mathrm{P}=\frac{\mathrm{C}_{\text {content }} / 12}{\mathrm{P}_{\text {content }} / 31}$

\section{Statistical analysis}

Three-factor analysis of variance (ANOVA) followed by Tukey HSD post-hoc analysis was used to determine differences in results for atomic ratios of $\mathrm{C}: \mathrm{N}, \mathrm{C}: \mathrm{P}$ and $\mathrm{N}: \mathrm{P}$ across treatments with target tree species, soil depths and sampling time (2007 and 2018) as factors. Additionally, twofactor analysis of variance (ANOVA) followed by Tukey HSD post-hoc analysis was used to determine differences in results for atomic ratios of $\mathrm{C}: \mathrm{N}, \mathrm{C}: \mathrm{P}$ and $\mathrm{N}: \mathrm{P}$ across treatments in the same soil depths with target tree species and sampling time as factors. Besides, one-factor analysis of variance (ANOVA) followed by Tukey HSD post-hoc analysis and was used to examine the 
153 differences in results for atomic ratios of $\mathrm{C}: \mathrm{N}, \mathrm{C}: \mathrm{P}$ and $\mathrm{N}: \mathrm{P}$ across the same sampling times and 154 soil depth between different target tree species. Before analysis, the normality and the homogeneity 155 of the residuals for data were examined by Shapiro-Wilk test and by Kolmogorov-Smirnov test in 156 the 'stats' package, respectively. If assumption of ANOVA of a given variable was met, we do ANOVA consequently. Otherwise, the non-parametric Kruskal-Wallis test was performed and the Wilcoxon test was performed in multiple comparisons. For all analyses, the significant level were set at $\alpha=0.05$. Besides, the differences between the two sampling events (2018 versus 2007) were compared with student's t-test or Wilcoxon test. Pearson correlation analysis was used to examine the correlations among TB, understory plant biomass (UPB), TAB, TB/TAB, understory plant biomass/total aboveground biomass (UPB/TAB), FRB, diversity indices of plant community (Richness index, Margale'f index, Shannon-Wiener index, Simpson index and Pielou index), LS, $\mathrm{C}, \mathrm{N}$ and $\mathrm{P}$ content, $\mathrm{C}: \mathrm{N}: \mathrm{P}$ stoichiometric ratios in litter and $\mathrm{C}: \mathrm{N}: \mathrm{P}$ stoichiometric ratios in topsoil. Additionally, the main influencing factors were selected by multiple linear regression using "stepAIC” function (R package: MASS) (Venables \& Ripley 2010) in R version 3.5.2. Furthermore, the corresponding contribution of selected factors were obtained by "relimpo" function ( $R$ package: relimpo) (Groemping 2006) in $\mathrm{R}$ version 3.5.2. Finally, the determinant factors of soil $\mathrm{C}: \mathrm{N}: \mathrm{P}$ stoichiometry at the $0-10 \mathrm{~cm}$ layers were examined with multiple regression, with FRB, LS, TB/TAB, Margalef's index, $\mathrm{C}$ and $\mathrm{P}$ contents in litter as independent variables.

\section{Results}

\section{Soil C, N and P stoichiometry}

Soil C: N and N:P varied among soil depths and between sampling times (Table 2; Figs. 1A-F). Soil C:P was responsive to tree species, soil depth, sampling time and interactive effect of tree species by soil depth (Table 2; Figs. 1G-I).

\section{Dynamics of Soil $\mathrm{C}, \mathrm{N}$ and $\mathrm{P}$ stoichiometry}

In 2007, only the $\mathrm{C}: \mathrm{N}$ ratio of soil at the depth of $10-20 \mathrm{~cm}$ varied significantly with tree species (Fig. 1B). Specifically, the highest C:N ratio was observed in soil of the PT plantation, followed by $\mathrm{CJ}$ plantation and shrubland, and the lowest $\mathrm{C}: \mathrm{N}$ ratio was observed in the soil of the LAR plantation (Fig. 1B). In 2018, both the C:N ratios of soil at the depths of 0-10 cm and 10-20 cm varied significantly with tree species (Figs. 1A\&B). At the depth of $0-10 \mathrm{~cm}$ the highest C:N ratio in soil were observed in soil of the LAR plantations, followed by PT and CJ plantations, and the lowest C:N ratio occurred in the soil of the shrubland (Fig. 1A). At the depth of 10-20 cm, the highest $\mathrm{C}$ : $\mathrm{N}$ ratio in soil was observed in soil of the PT plantation, followed by shrubland and LAR 
186

187

188

189

190

191

192

193

194

195

196

197

198

199

200

201

202

203

204

205

206

207

208

209

210

211

212

213

214

215

216

217

218

219

plantations and the lowest $\mathrm{C}: \mathrm{N}$ ratio was observed in the soil of the CJ plantations (Fig. 1B).

In 2007, the N:P ratio of soil varied significantly with tree species for the depth of 0-10 cm and 20-30 cm (Fig. 1D\&F). At the depth of $0-10 \mathrm{~cm}$ the highest N:P ratio of soil was observed in shrubland, followed by LAR and PT plantations, and the lowest N:P ratio of soil occurred in the CJ plantation (Fig. 1D). At the depth of $20-30 \mathrm{~cm}$, the highest N:P ratio in soil was observed in soil of the CJ plantation, followed by shrubland and LAR plantations and the lowest C:N ratio was observed in the soil of the PT plantations (Fig. 1F). In 2018, only the N:P ratio of soil at the depth of $0-10 \mathrm{~cm}$ varied significantly with tree species (Fig. 1D). The trend was same as that at the depth of $0-10 \mathrm{~cm}$ in 2007 (Fig. 1D).

In 2007, the C:P of soil at the depth of 0-10 cm varied with tree species (Fig. 1G). Specifically, the highest $\mathrm{C}: \mathrm{P}$ of soil was observed in e shrubland, followed by LAR and PT plantations, and the lowest C:P of soil was observed in the CJ plantation (Fig. 1G). In 2018, the C:P ratios of soil at the depth of $0-10 \mathrm{~cm}$ and $10-20 \mathrm{~cm}$ have shown similar trend as 2007 , however the soil at the depth of 20-30 cm has shown significant differences among tree species (Figs. 1G-I). Specifically, at the depth of 20-30 cm the highest $\mathrm{C}: \mathrm{N}$ ratio of soil were observed in soil of the shrubland, followed by $\mathrm{CJ}$ and PT plantations, and the lowest $\mathrm{C}: \mathrm{N}$ ratio of soil was observed in the LAR plantations (Fig. 1I).

\section{Correlations among soil $\mathrm{C}: \mathrm{N}: \mathrm{P}$ stoichiometric ratios, soil properties and plant community}

\section{attributes in 2018}

Across soil profiles, the C:N, N:P and C:P significantly decreased with the increase in soil bulk density, whereas significantly increased with the increase in soil moisture and FRB (Fig. 2). At the topsoil, the $\mathrm{C}: \mathrm{N}$ was significantly positively correlated to $\mathrm{LS}(P<0.001)$, whereas negatively correlated to FRB and $\mathrm{C}$ content of litter $(P<0.05)$ (Table 3). The N:P was significantly positively correlated to UPB $(P<0.001)$, UPB/TAB $(P<0.001)$, tree \& shrub richness $(P<0.001)$, Margalef's index $(P<0.001)$, Shannon-Wiener index $(P<0.001)$, Pielou evenness index $(P<0.001)$, but negatively correlated to TB $(P<0.001)$, TAB $(P<0.001)$, TB/TAB $(P<0.001)$, P content of litter $(P<0 \cdot 05)$ and Simpson dominance index $(P<0.001)$ (Table 3). The C:P was significantly positively correlated to tree $\&$ shrub richness $(P<0.001)$, Margalef's index $(P<0.001)$, Shannon-Wiener index $(P<0.001)$, Pielou evenness index $(P<0.001)$, but negatively correlated to $\mathrm{TB}(P<0.001)$, TAB $(P<0.001)$, TB/TAB $(P<0.05), \mathrm{C}$ content of litter $(P<0.05)$, litter $\mathrm{C}: \mathrm{N}(P<0.05)$ and Simpson index $(P<0.001)$ (Table 3).

Soil C:N at the topsoil was affected by LS and FRB ( $\left.r^{2}=0.76, F=13.96, P=0.002\right)$, and the LS contributed to $67.31 \%$ of the variation (Fig. 3). Soil N:P at the topsoil was affected by $\mathrm{P}$ content of litter, Margalef's index and TB/TAB $\left(r^{2}=0.98, F=120.50, P<0.001\right)$, and TB/TAB and 
220 Margalef's index contributed to $48 \%$ and 38\% of the variation, respectively (Fig. 3). Soil C:P at

221 the topsoil was affected by $\mathrm{C}$ content of litter and Margalef's index $\left(r^{2}=0.81, F=19.27, P<0.001\right)$, 222 and the Margalef's index contributed to $75 \%$ of the variation (Fig. 3).

\section{Discussion}

\section{Soil C:N:P ecological stoichiometry for plantations in subalpine region}

In our experiment soil $\mathrm{C}: \mathrm{N}$ at the depth of $0-30 \mathrm{~cm}$ ranges from 14.5 to 15.5 in the examined ecosystems, which is slightly higher than the global average $\mathrm{C}: \mathrm{N}$ of 14.3 (Yue et al. 2017) and lower than the other subalpine average C:N (Bing et al. 2016). Soil C:P at the depth of 0-30 cm ranges from 184 to 299 in the examined ecosystems, which is higher than China's average of 136 (Tian et al. 2010), lower than the global average and the other subalpine (Bing et al. 2016; Yue et al. 2017). Soil N:P at the depth of $0-30 \mathrm{~cm}$ ranges from 12.9 to 19.4 , which is higher than that of global and China's average (9.3 and13.1, respectively) (Tian et al. 2010; Yue et al. 2017) and lower than the other subalpine average C:N (Bing et al. 2016). What account for the discrepancy across studies are largely unknown.

\section{Soil C:N:P ecological stoichiometry between tree species}

In accordance with our first hypothesis, soil $\mathrm{C}: \mathrm{N}: \mathrm{P}$ stoichiometry varied significantly with tree species (Table 2; Fig. 1), particularly for the topsoil, where $\mathrm{C}: \mathrm{N}$ ratios in LAR and PT plantations are greater than CJ plantation and shrubland, implying higher $\mathrm{N}$ mineralization rate in shrubland. Three likely reasons account for this finding. Firstly, litter inputs and stocks differ across the examined plantations (Table 4). In the topsoil, LS was the most influencing factor of soil C:N (Fig. 3). Secondly, the microclimate, the quantity and quality of root exudates and rhizodeposits as well as soil microbial community change with plant species (Aoki et al. 2012; Ohta \& Hiura 2016; Zhang et al. 2011), which may jointly influence soil nutrient status and its stoichiometric ratio. Firstly, as shown by previous studies, broadleaf litter is more decomposable than needle litter in boreal forests (Laganiere et al. 2010). Besides, allocation of $\mathrm{C}$ to roots is directly proportional to photosynthesis (Brzostek et al. 2015) and understory shrubs generally have a lower photosynthetic capacity than overstory trees (Sakai et al. 2005). Nevertheless, the C:N ratio of conifer stands is greater than broadleaf stands may be related to the canopy density and high light interception of conifers reduce the light efficiency on the forest floor (Lieffers et al. 1999). Furthermore, the decomposition rates of broadleaf trees are commonly higher in comparison with conifer trees (Taylor et al. 1989; Zhang et al. 2019a).

\section{Vertical pattern of soil $C: N: P$ ecological stoichiometry}

Consistent with our second hypothesis, the C:N, C:P and N:P of soil decreased with increase in the soil depth (Fig. 1). This finding is in agreement with previous studies addressing vertical 
254 pattern of soil C:N:P stoichiometry in forest soils (Feng et al. 2017; Li et al. 2013; Qiao et al. 2020; 255 Tian et al. 2010; Tischer et al. 2014). These results are maybe related to the fact that soil nutrients 256 decreased with soil depth. Besides, this could be due to the topsoil layer environmental factors 257 being easily affected and the return of nutrients from litters (Feng et al. 2017). In addition, soil

258

259

260

261

262

263

264

265

266

267

268

269

270

271

272

273

274

275

276

277

278

279

280

281

282

283

284

285

286

287

nutrients are usually first concentrated on the topsoil and then transferred to the subsoil layer with water or soil animals. Furthermore, soil C:N ratio decreased with the soil depth among different plantations, and this could be related to the different nutrient turnover rates in decomposition process. The easily decomposable material elapsed and $\mathrm{N}$ is fixed in decayed products and microbial biomass, remaining durable materials had more slowly decomposition rates and lower $\mathrm{C}: \mathrm{N}$ ratio (Yang et al. 2010). Compared with the topsoil layer, the organic matter in subsoil layer is more humified and older, result in continuous decrease of the soil $\mathrm{C}: \mathrm{N}$ ratio with soil depth (Callesen et al. 2007; Yang et al. 2010). Additionally, difference in soil nutrient associated with changes in soil microbial dynamics, litter decomposition, microbial food web, and soil nutrient accumulation and circulation (Griffiths et al. 2012; Zhao et al. 2015). Besides, the decrease in soil temperature with the increase of soil depth (Jackson et al. 2000) may account for the decreased soil C:N:P stoichiometric ratios in lower depth.

\section{Potential influencing factors of soil C:N:P stoichiometry}

In partial agreement with our third hypothesis, linkage among soil C:N:P ecological stoichiometry, soil properties and plant community attributes varied with soil depth. This is also in agreement with our earlier result (Feng et al. 2017), the relative contribution of factors varied among soil depths and the examined object. Firstly, bulk density increased with the increase in soil depth, result in decreased soil porosity, which further reduce soil moisture and root penetration. Besides, the topsoil of trees is in direct contact with the plant community. Hence, LS, TB/TAB and other plant community structure index will effect on it. Additionally, the correlations between environmental factors and stoichiometric ratios depended on the elements considered. In summary, the effects of tree species and soil depth on soil C:N:P stoichiometry associated with bulk density, soil moisture, the quantity and quality of aboveground litter inputs and underground fine root.

\section{Conclusions}

We observed that tree-specific and depth-dependent have strong effects on soil $\mathrm{C}: \mathrm{N}: \mathrm{P}$ stoichiometry in subalpine plantations. In general, the $\mathrm{C}: \mathrm{N}, \mathrm{C}: \mathrm{P}$ and $\mathrm{N}: \mathrm{P}$ of topsoil are higher in comparing with that of subsoil layer at $0-30 \mathrm{~cm}$ depth profiles. The difference in $\mathrm{C}: \mathrm{N}, \mathrm{N}: \mathrm{P}$ and $\mathrm{C}: \mathrm{P}$ at the topsoil across target tree species significantly linked to standing litter stock, tree biomass/aboveground biomass and Margalef's index of plant community, respectively, whereas

Peer) reviewing PDF | (2019:12:44277:3:0:NEW 12 Jul 2020) 
288 the observed variations of $\mathrm{C}: \mathrm{N}, \mathrm{N}: \mathrm{P}$ and $\mathrm{C}: \mathrm{P}$ ratio among soil profiles are closely related to 289 differences in soil bulk density, soil moisture, the quantity and quality of aboveground litter inputs 290 and underground fine root across plantations examined. Our results highlight that soil nutrients 291 status in plantation depend on litter quantity and quality of selected tree species, as well as soil 292 physical attributes. Therefore, matching site with trees is crucial to enhance ecological functioning 293 in degraded regions resulting from human activity.

294 Acknowledgements

295 This study was jointly funded by the Major Science Technology Project of Sichuan Province 296 (Grant numbers: 2018SZDZXD035). We thank De feng Feng and Xin Liu for helpful suggestions 297 on the study and earlier version of the manuscript. We also highly appreciated Long Huang, 298 Shuang ping Peng and Zhong ping Tang for their assistance and support provided in sample 299 collection and analysis. All authors have no conflict of interests to declare. 


\section{References}

Alberti G, Vicca S, Inglima I, Belelli-Marchesini L, Genesio L, Miglietta F, Marjanovic H, Martinez C, Matteucci G, D'Andrea E, Peressotti A, Petrella F, Rodeghiero M, and Cotrufo MF. 2015. Soil C:N stoichiometry controls carbon sink partitioning between above-ground tree biomass and soil organic matter in high fertility forests. Iforest-Biogeosciences and Forestry 8:195-206. 10.3832/ifor1196-008

Aoki M, Fujii K, and Kitayama K. 2012. Environmental Control of Root Exudation of Low-Molecular Weight Organic Acids in Tropical Rainforests. Ecosystems 15:1194-1203. 10.1007/s10021-012-9575-6

Aponte C, Garcia LV, and Maranon T. 2012. Tree Species Effect on Litter Decomposition and Nutrient Release in Mediterranean Oak Forests Changes Over Time. Ecosystems 15:1204-1218. 10.1007/s10021-012-9577-4

Bing H, Wu Y, Zhou J, Sun H, Luo J, Wang J, and Yu D. 2016. Stoichiometric variation of carbon, nitrogen, and phosphorus in soils and its implication for nutrient limitation in alpine ecosystem of Eastern Tibetan Plateau. Journal of Soils and Sediments 16:405-416. 10.1007/s11368-015-1200-9

Bowman RA. 1988. A RAPID METHOD TO DETERMINE TOTAL PHOSPHORUS IN SOILS. Soil Science Society of America Journal 52:1301-1304. 10.2136/sssaj1988.03615995005200050016x

Brzostek ER, Dragoni D, Brown ZA, and Phillips RP. 2015. Mycorrhizal type determines the magnitude and direction of root-induced changes in decomposition in a temperate forest. New Phytologist 206:1274-1282. 10.1111/nph.13303

Callesen I, Raulund-Rasmussen K, Westman CJ, and Tau-Strand L. 2007. Nitrogen pools and C : N ratios in welldrained Nordic forest soils related to climate and soil texture. Boreal Environment Research 12:681-692.

Cambardella CA, and Elliott ET. 1992. PARTICULATE SOIL ORGANIC-MATTER CHANGES ACROSS A GRASSLAND CULTIVATION SEQUENCE. Soil Science Society of America Journal 56:777-783. 10.2136/sssaj1992.03615995005600030017x

Cleveland CC, and Liptzin D. 2007. C : N : P stoichiometry in soil: is there a "Redfield ratio" for the microbial biomass? Biogeochemistry 85:235-252. 10.1007/s10533-007-9132-0

Cools N, Vesterdal L, De Vos B, Vanguelova E, and Hansen K. 2014. Tree species is the major factor explaining C:N ratios in European forest soils. Forest Ecology and Management 311:3-16. 10.1016/j.foreco.2013.06.047

Daufresne T, and Loreau M. 2001. Ecological stoichiometry, primary producer-decomposer interactions, and ecosystem persistence. Ecology 82:3069-3082. 10.2307/2679835

Davis M, Nordmeyer A, Henley D, and Watt M. 2007. Ecosystem carbon accretion 10 years after afforestation of depleted subhumid grassland planted with three densities of Pinus nigra. Global Change Biology 13:14141422. 10.1111/j.1365-2486.2007.01372.x

Deng L, Liu G-B, and Shangguan Z-P. 2014. Land-use conversion and changing soil carbon stocks in China's 'Grainfor-Green' Program: a synthesis. Global Change Biology 20:3544-3556. 10.1111/gcb.12508

Elser JJ. 2000. Ecological stoichiometry: from sea lake to land. Trends in Ecology \& Evolution 15:393-394. 10.1016/s0169-5347(00)01956-x

Elser JJ, Bracken MES, Cleland EE, Gruner DS, Harpole WS, Hillebrand H, Ngai JT, Seabloom EW, Shurin JB, and Smith JE. 2007. Global analysis of nitrogen and phosphorus limitation of primary producers in freshwater, marine and terrestrial ecosystems. Ecology Letters 10:1135-1142. 10.1111/j.1461-0248.2007.01113.x

Feng D, and Bao W. 2018. Shrub encroachment alters topsoil C:N:P stoichiometric ratios in a high-altitude forest cutover. Iforest-Biogeosciences and Forestry 11:594-598. 10.3832/ifor2803-011 
Feng D, Bao W, and Pang X. 2017. Consistent profile pattern and spatial variation of soil C/N/P stoichiometric ratios in the subalpine forests. Journal of Soils and Sediments 17:2054-2065. 10.1007/s11368-017-1665-9

Griffiths BS, A. Spilles, and M. Bonkowski. 2012. C:N:P stoichiometry and nutrient limitation of the soil microbial biomass in a grazed grassland site under experimental P limitation or excess. Ecological Processes 1:1-6.

Groemping U. 2006. Relative importance for linear regression in R: The package relaimpo. Journal of Statistical Software 17. 10.18637/jss.v017.i01

Gusewell S. 2004. N : P ratios in terrestrial plants: variation and functional significance. New Phytologist 164:243266. 10.1111/j.1469-8137.2004.01192.x

Gusewell S, Jewell PL, and Edwards PJ. 2005. Effects of heterogeneous habitat use by cattle on nutrient availability and litter decomposition in soils of an Alpine pasture. Plant and Soil 268:135-149. 10.1007/s11104-0040304-6

Hessen DO, Agren GI, Anderson TR, Elser JJ, and De Ruiter PC. 2004. Carbon, sequestration in ecosystems: The role of stoichiometry. Ecology 85:1179-1192. 10.1890/02-0251

Jackson RB, Schenk HJ, Jobbagy EG, Canadell J, Colello GD, Dickinson RE, Field CB, Friedlingstein P, Heimann M, Hibbard K, Kicklighter DW, Kleidon A, Neilson RP, Parton WJ, Sala OE, and Sykes MT. 2000. Belowground consequences of vegetation change and their treatment in models. Ecological Applications 10:470-483. 10.1890/1051-0761(2000)010[0470:bcovca]2.0.co;2

Jiang Y, Pang X, and Bao W. 2011. Soil microbial biomass and the influencing factors under Pinus tabulaeformis and Picea asperata plantations in the upper Minjiang River. Acta Ecologica Sinica 31:801-811.

Laganiere J, Pare D, and Bradley RL. 2010. How does a tree species influence litter decomposition? Separating the relative contribution of litter quality, litter mixing, and forest floor conditions. Canadian Journal of Forest Research-Revue Canadienne De Recherche Forestiere 40:465-475. 10.1139/x09-208

Lawrence BA, Fahey TJ, and Zedler JB. 2013. Root dynamics of Carex stricta-dominated tussock meadows. Plant and Soil 364:325-339. 10.1007/s11104-012-1360-y

Li H, Li J, He Y, Li S, Liang Z, Peng C, Polle A, and Luo Z-B. 2013. Changes in carbon, nutrients and stoichiometric relations under different soil depths, plant tissues and ages in black locust plantations. Acta Physiologiae Plantarum 35:2951-2964. 10.1007/s11738-013-1326-6

Li R, Kan S, Zhu M, Chen J, Ai X, Chen Z, Zhang J, and Ai Y. 2018. Effect of different vegetation restoration types on fundamental parameters, structural characteristics and the soil quality index of artificial soil. Soil \& Tillage Research 184:11-23. 10.1016/j.still.2018.06.010

Lieffers VJ, Messier C, Stadt KJ, Gendron F, and Comeau PG. 1999. Predicting and managing light in the understory of boreal forests. Canadian Journal of Forest Research 29:796-811. 10.1139/cjfr-29-6-796

Moser G, Leuschner C, Hertel D, Graefe S, Soethe N, and Iost S. 2011. Elevation effects on the carbon budget of tropical mountain forests (S Ecuador): the role of the belowground compartment. Global Change Biology 17:2211-2226. 10.1111/j.1365-2486.2010.02367.x

Mueller M, Oelmann Y, Schickhoff U, Boehner J, and Scholten T. 2017. Himalayan treeline soil and foliar C:N:P stoichiometry indicate nutrient shortage with elevation. Geoderma 291:21-32. 10.1016/j.geoderma.2016.12.015

Ohta T, and Hiura T. 2016. Root exudation of low-molecular-mass-organic acids by six tree species alters the dynamics of calcium and magnesium in soil. Canadian Journal of Soil Science 96:199-206. 10.1139/cjss2015-0063

Peer) reviewing PDF | (2019:12:44277:3:0:NEW 12 Jul 2020) 
381

382

383

384

385

386

387

388

389

390

391

392

393

394

395

396

397

398

399

400

401

402

403

404

405

406

407

408

409

410

411

412

413

414

415

416

417

418

419

420

421

Pang X, and Bao W. 2011. Effect of Substituting Plantation Species for Native Shrubs on the Water-holding Characteristics of the Forest Floor on the Eastern Tibetan Plateau. Journal of Resources and Ecology 2:217224.

Paterson E, Gebbing T, Abel C, Sim A, and Telfer G. 2007. Rhizodeposition shapes rhizosphere microbial community structure in organic soil. New Phytologist 173:600-610. 10.1111/j.1469-8137.2006.01931.x

Prescott CE, and Grayston SJ. 2013. Tree species influence on microbial communities in litter and soil: Current knowledge and research needs. Forest Ecology and Management 309:19-27. 10.1016/j.foreco.2013.02.034

Qiao Y, Wang J, Liu HM, Huang K, Yang QS, Lu RL, Yan LM, Wang XH, and Xia JY. 2020. Depth-dependent soil C-N-P stoichiometry in a mature subtropical broadleaf forest. Geoderma 370:9. 10.1016/j.geoderma.2020.114357

Qu L, Huang Y, Ma K, Zhang Y, and Biere A. 2016. Effects of plant cover on properties of rhizosphere and interplant soil in a semiarid valley, SW China. Soil Biology \& Biochemistry 94:1-9. 10.1016/j.soilbio.2015.11.004

Reich PB, and Oleksyn J. 2004. Global patterns of plant leaf N and P in relation to temperature and latitude. Proceedings of the National Academy of Sciences of the United States of America 101:11001-11006. 10.1073/pnas.0403588101

Sakai T, Saigusa N, Yamamoto S, and Akiyama T. 2005. Microsite variation in light availability and photosynthesis in a cool-temperate deciduous broadleaf forest in central Japan. Ecological Research 20:537-545. 10.1007/s11284-005-0067-4

Sardans J, Rivas-Ubach A, and Penuelas J. 2012. The C:N:P stoichiometry of organisms and ecosystems in a changing world: A review and perspectives. Perspectives in Plant Ecology Evolution and Systematics 14:33-47. 10.1016/j.ppees.2011.08.002

Taylor BR, Parkinson D, and Parsons WFJ. 1989. NITROGEN AND LIGNIN CONTENT AS PREDICTORS OF LITTER DECAY-RATES - A MICROCOSM TEST. Ecology 70:97-104. 10.2307/1938416

Tessier JT, and Raynal DJ. 2003. Vernal nitrogen and phosphorus retention by forest understory vegetation and soil microbes. Plant and Soil 256:443-453. 10.1023/a:1026163313038

Tian H, Chen G, Zhang C, Melillo JM, and Hall CAS. 2010. Pattern and variation of C:N:P ratios in China's soils: a synthesis of observational data. Biogeochemistry 98:139-151. 10.1007/s10533-009-9382-0

Tischer A, Potthast K, and Hamer U. 2014. Land-use and soil depth affect resource and microbial stoichiometry in a tropical mountain rainforest region of southern Ecuador. Oecologia 175:375-393. 10.1007/s00442-0142894-x

Venables WN, and Ripley BD. 2010. Modern Applied Statistics with S.

Vesterdal L, Schmidt IK, Callesen I, Nilsson LO, and Gundersen P. 2008. Carbon and nitrogen in forest floor and mineral soil under six common European tree species. Forest Ecology and Management 255:35-48. 10.1016/j.foreco.2007.08.015

Vinton MA, and Burke IC. 1995. INTERACTIONS BETWEEN INDIVIDUAL PLANT-SPECIES AND SOIL NUTRIENT STATUS IN SHORTGRASS STEPPE. Ecology 76:1116-1133. 10.2307/1940920

Vitousek PM, and Howarth RW. 1991. NITROGEN LIMITATION ON LAND AND IN THE SEA - HOW CAN IT OCCUR. Biogeochemistry 13:87-115.

Whitaker J, Ostle N, Nottingham AT, Ccahuana A, Salinas N, Bardgett RD, Meir P, and McNamara NP. 2014. Microbial community composition explains soil respiration responses to changing carbon inputs along an Andes-to-Amazon elevation gradient. Journal of Ecology 102:1058-1071. 10.1111/1365-2745.12247

Peer) reviewing PDF | (2019:12:44277:3:0:NEW 12 Jul 2020) 
422

423

424

425

426

427

428

429

430

431

432

433

434

435

436

437

438

439

440

441

442

443

444

445

446

447

448

Xu X, Thornton PE, and Post WM. 2013. A global analysis of soil microbial biomass carbon, nitrogen and phosphorus in terrestrial ecosystems. Global Ecology and Biogeography 22:737-749. 10.1111/geb.12029

Yang Y, Wang G, Shen H, Yang Y, Cui H, and Liu Q. 2014. Dynamics of carbon and nitrogen accumulation and C:N stoichiometry in a deciduous broadleaf forest of deglaciated terrain in the eastern Tibetan Plateau. Forest Ecology and Management 312:10-18. 10.1016/j.foreco.2013.10.028

Yang YH, Fang JY, D. L Guo, C. J Ji, and Ma WH. 2010. Vertical patterns of soil carbon, nitrogen and carbon: nitrogen stoichiometry in Tibetan grasslands. Biogeosciences Discuss:1-24. /10.5194/bgd-7-1-2010

Yu Q, Wilcox K, La Pierre K, Knapp AK, Han X, and Smith MD. 2015. Stoichiometric homeostasis predicts plant species dominance, temporal stability, and responses to global change. Ecology 96:2328-2335. 10.1890/141897.1

Yue K, Fornara DA, Yang W, Peng Y, Li Z, Wu F, and Peng C. 2017. Effects of three global change drivers on terrestrial C:N:P stoichiometry: a global synthesis. Global Change Biology 23:2450-2463. $10.1111 / \mathrm{gcb} .13569$

Zechmeister-Boltenstern S, Keiblinger KM, Mooshammer M, Penuelas J, Richter A, Sardans J, and Wanek W. 2015. The application of ecological stoichiometry to plant-microbial-soil organic matter transformations. Ecological Monographs 85:133-155. 10.1890/14-0777.1

Zhang C, Liu G, Xue S, and Song Z. 2011. Rhizosphere soil microbial activity under different vegetation types on the Loess Plateau, China. Geoderma 161:115-125. 10.1016/j.geoderma.2010.12.003

Zhang MH, Cheng XL, Geng QH, Shi Z, Luo YQ, and Xu X. 2019a. Leaf litter traits predominantly control litter decomposition in streams worldwide. Global Ecology and Biogeography 28:1469-1486. 10.1111/geb.12966

Zhang Y, Li C, and Wang M. 2019b. Linkages of C: N: P stoichiometry between soil and leaf and their response to climatic factors along altitudinal gradients. Journal of Soils and Sediments 19:1820-1829. 10.1007/s11368018-2173-2

Zhao F, Kang D, Han X, Yang G, Yang G, Feng Y, and Ren G. 2015. Soil stoichiometry and carbon storage in longterm afforestation soil affected by understory vegetation diversity. Ecological Engineering 74:415-422. 10.1016/j.ecoleng.2014.11.010

Peer) reviewing PDF | (2019:12:44277:3:0:NEW 12 Jul 2020) 


\section{Figure 1}

Soil C:N:P stoichiometric ratios across soil depth, tree species and sampling times

The capital and lower-case letters indicate significant differences across different tree species $(P<0.05)$ in 2018 and 2007 , respectively. The NS, $*$ and $* *$ denote the differences between sampling time (2018 versus 2007) based on t-test or Wilcoxon test are at $P>0.05$, $0.01 \leq P \leq 0.05$ and $P<0.01$, respectively.
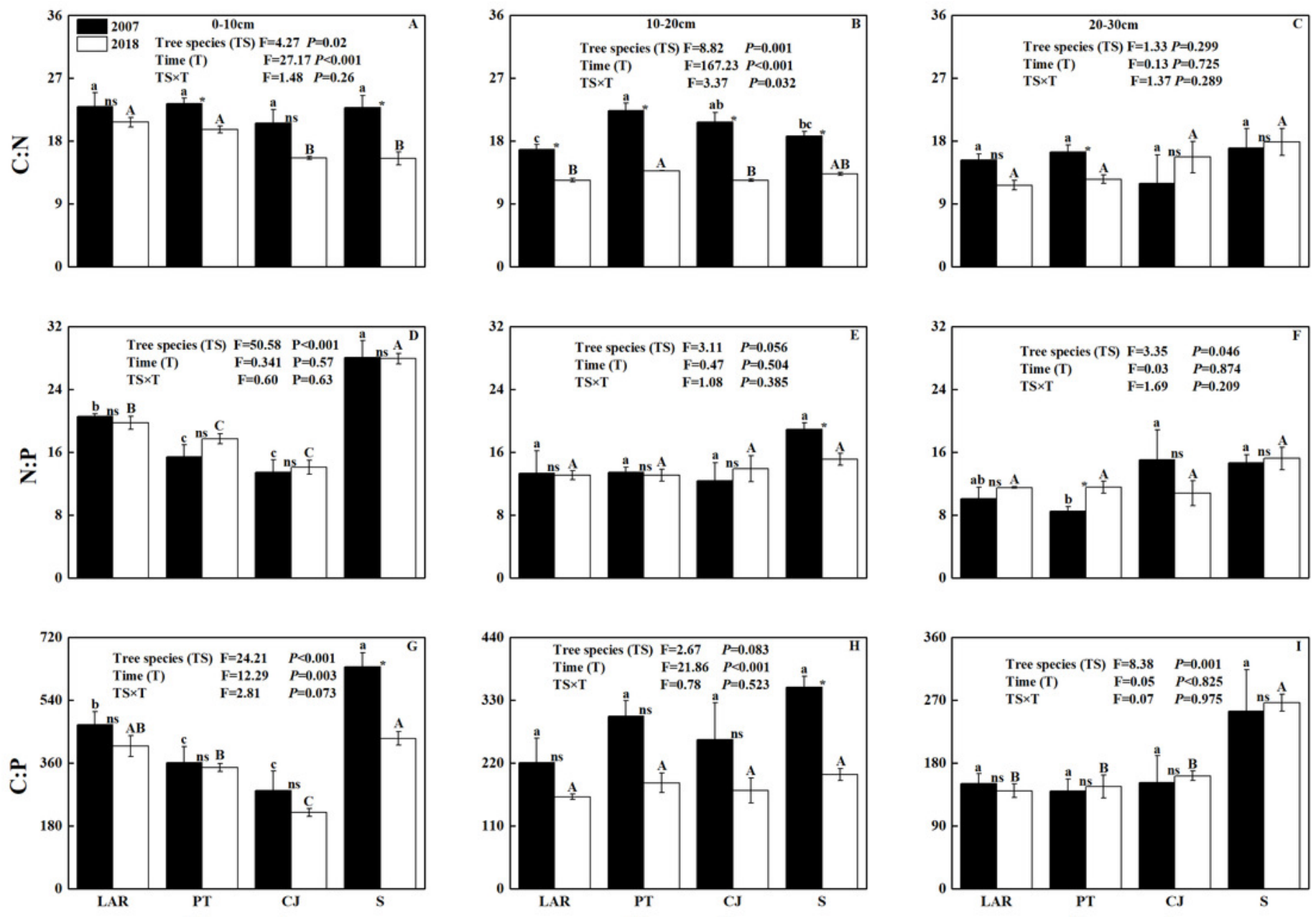

Tree species

Tree species

Tree species 
Figure 2

Relationships between $\mathrm{C}: \mathrm{N}: \mathrm{P}$ stoichiometric ratio and bulk density, fine root biomass and soil moisture at $0-30 \mathrm{~cm}$ of soil profiles in 2018
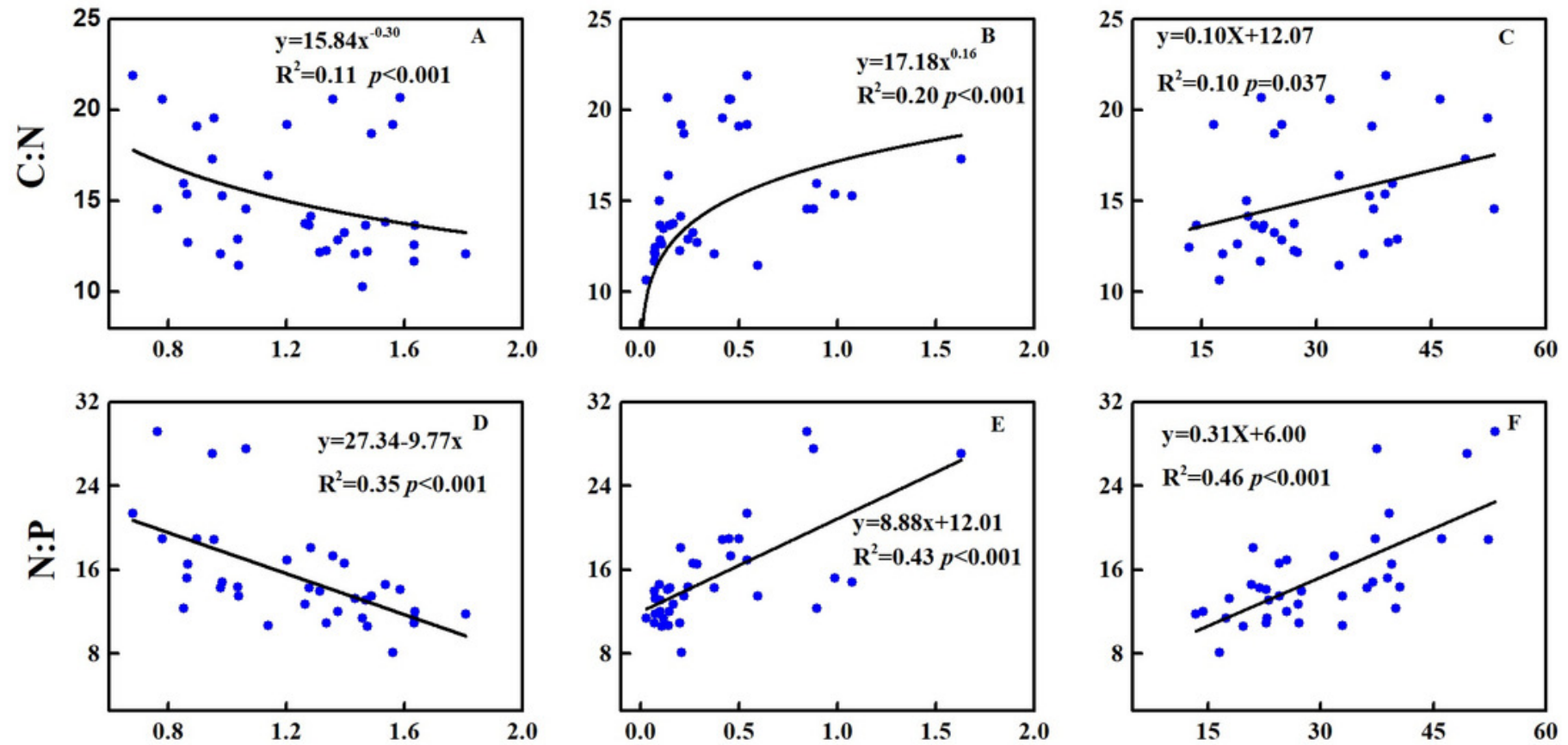

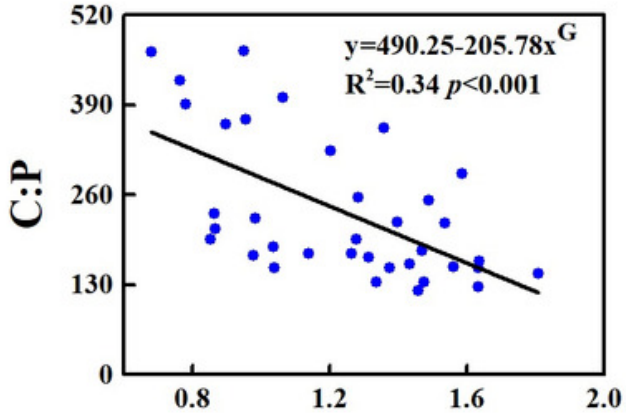

Bulk Density $\left(\mathrm{g} / \mathrm{cm}^{3}\right)$

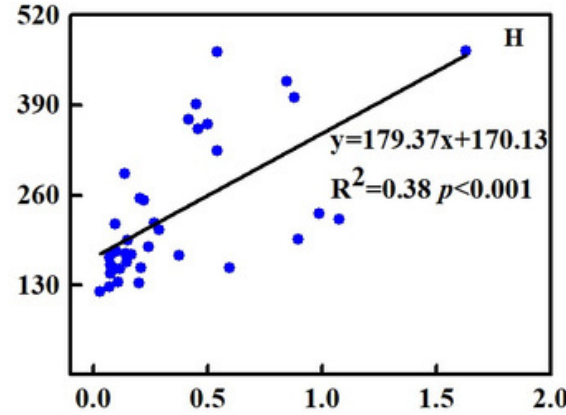

Fine root biomass(t/ha)

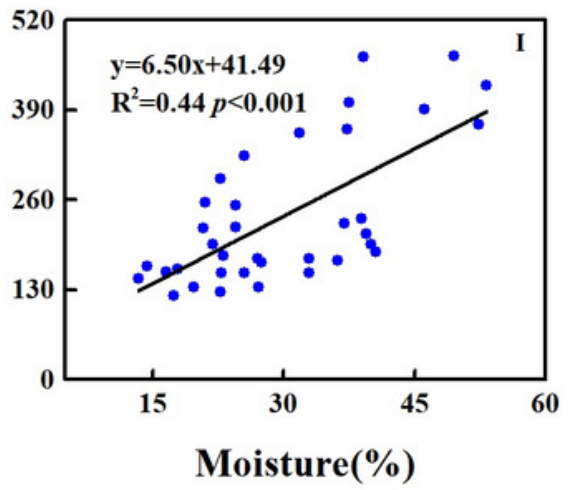


Figure 3

The gradient boost decision tree measuring the relative importance of factor influencing topsoil $(0-10 \mathrm{~cm})$

Note: C:N:P stoichiometric ratio in 2018. FRB_Fine root biomass; LS_Litter stock; TB:TAB_Tree biomass/Total aboveground biomass; MI_Margalef index; L-P_Litter phosphorus; L-C_Litter carbon. ${ }_{-}^{*} P<0.05, * * \_P<0.001$.

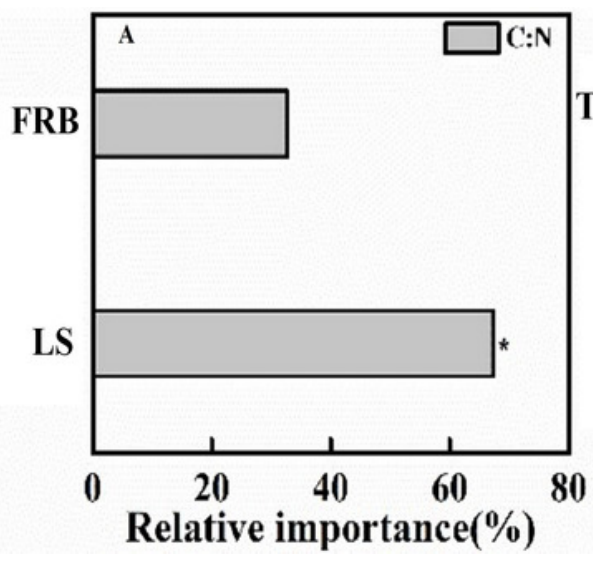

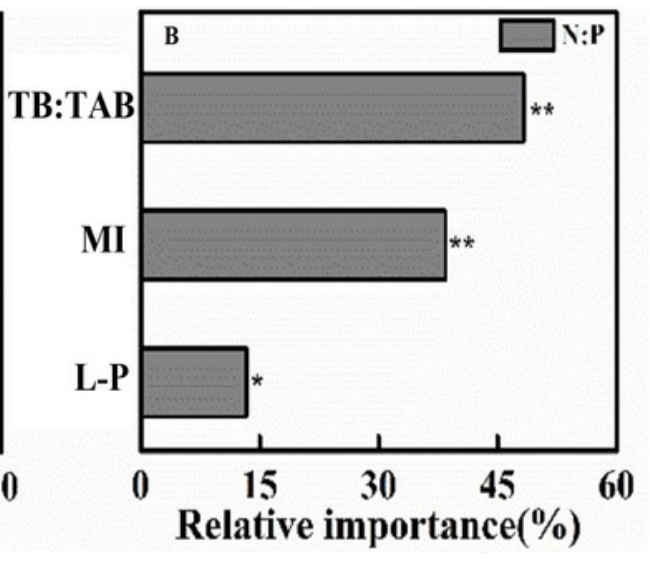




\section{Table $\mathbf{1}$ (on next page)}

The basic information of plantation stands

Note: LAR_Larix kaempferi; PT_Pinus tabulaeformis; CJ_Cercidiphyllum japonicum; S_ Shrubland. Height_Tree height; DBH_Diameter at breast height; SD_Stand density. 


\begin{tabular}{|c|c|c|c|c|c|c|c|c|}
\hline $\begin{array}{l}\text { Species } \\
\text { identity }\end{array}$ & Location & Elevation (m) & Aspect & Slope $\left({ }^{\circ}\right)$ & $\begin{array}{l}\text { Canopy } \\
\text { density }\end{array}$ & Height (m) & $\mathrm{DBH}(\mathrm{cm})$ & $\begin{array}{c}\text { SD (trees ha } \\
1)\end{array}$ \\
\hline \multirow[t]{3}{*}{ LAR } & $31^{\circ} 41^{\prime} 23^{\prime \prime} \mathrm{E}, 103^{\circ} 53^{\prime} 42^{\prime \prime} \mathrm{N}$ & 2070 & $\mathrm{NE}$ & 14 & 0.9 & 11.69 & 16.29 & 1200 \\
\hline & $31^{\circ} 41^{\prime} 23^{\prime \prime} \mathrm{E}, 103^{\circ} 53^{\prime} 43^{\prime \prime} \mathrm{N}$ & 2070 & NE & 15 & 0.8 & 10.18 & 11.31 & 2200 \\
\hline & $31^{\circ} 41^{\prime} 22^{\prime \prime} \mathrm{E}, 103^{\circ} 53^{\prime} 42^{\prime \prime} \mathrm{N}$ & 2081 & $\mathrm{~N}$ & 21 & 0.98 & 11.62 & 13.66 & 1000 \\
\hline \multirow[t]{3}{*}{ PT } & $31^{\circ} 41^{\prime} 27^{\prime \prime} \mathrm{E}, 103^{\circ} 53^{\prime} 41^{\prime \prime} \mathrm{N}$ & 2066 & $\mathrm{~N}$ & 9 & 0.85 & 9.62 & 8.67 & 5100 \\
\hline & $31^{\circ} 41^{\prime} 26^{\prime \prime} \mathrm{E}, 103^{\circ} 53^{\prime} 42^{\prime \prime} \mathrm{N}$ & 2065 & $\mathrm{~N}$ & 6 & 0.89 & 11.68 & 10.89 & 4000 \\
\hline & $31^{\circ} 41^{\prime} 26^{\prime \prime} \mathrm{E}, 103^{\circ} 53^{\prime} 43^{\prime \prime} \mathrm{N}$ & 2073 & $\mathrm{~N}$ & 20 & 0.96 & 10.65 & 8.29 & 2700 \\
\hline \multirow[t]{3}{*}{$\mathrm{CJ}$} & $31^{\circ} 41^{\prime} 24^{\prime \prime} \mathrm{E}, 103^{\circ} 53^{\prime} 24^{\prime \prime} \mathrm{N}$ & 2056 & NW & 10 & 0.9 & 11.84 & 12.15 & 2900 \\
\hline & $31^{\circ} 41^{\prime} 26^{\prime \prime} \mathrm{E}, 103^{\circ} 53^{\prime} 39^{\prime \prime} \mathrm{N}$ & 2068 & NW & 19 & 0.93 & 11.47 & 11.97 & 3400 \\
\hline & $31^{\circ} 41^{\prime} 27^{\prime \prime} \mathrm{E}, 103^{\circ} 53^{\prime} 39^{\prime \prime} \mathrm{N}$ & 2020 & NW & 18 & 0.89 & 13.17 & 11.6 & 3300 \\
\hline \multirow[t]{3}{*}{ S } & $31^{\circ} 41^{\prime} 36^{\prime \prime} \mathrm{E}, 103^{\circ} 53^{\prime} 42^{\prime \prime} \mathrm{N}$ & 1933 & $\mathrm{~N}$ & 17 & 0.94 & 5.95 & 3.87 & 15100 \\
\hline & $31^{\circ} 41^{\prime} 35^{\prime \prime} \mathrm{E}, 103^{\circ} 53^{\prime} 41^{\prime \prime} \mathrm{N}$ & 1948 & NW & 22 & 0.9 & 3.9 & 2.81 & 15300 \\
\hline & $31^{\circ} 41^{\prime} 35^{\prime \prime} \mathrm{E}, 103^{\circ} 53^{\prime} 42^{\prime \prime} \mathrm{N}$ & 1953 & NW & 18 & 0.86 & 5.91 & 3.47 & 12500 \\
\hline
\end{tabular}

2 


\section{Table 2 (on next page)}

Summary of the linear mixed model showing the effects of soil layer, trees species and sampling time on the $\mathrm{C}: \mathrm{N}, \mathrm{N}: \mathrm{P}$ and $\mathrm{C}: \mathrm{P}$ of soil 


\begin{tabular}{|c|c|c|c|c|c|c|c|c|c|c|c|c|c|c|c|c|c|c|}
\hline \multirow{2}{*}{$\begin{array}{c}\text { Variable } \\
\mathrm{s} \\
\end{array}$} & \multicolumn{3}{|c|}{ Depth (D) } & \multicolumn{3}{|c|}{ Tree species (TS) } & \multicolumn{3}{|c|}{ Time (T) } & \multicolumn{3}{|c|}{$\mathrm{D} \times \mathrm{TS}$} & \multicolumn{3}{|c|}{$\mathrm{TS} \times \mathrm{T}$} & \multicolumn{3}{|c|}{$\mathrm{D} \times \mathrm{TS} \times \mathrm{T}$} \\
\hline & d.f. & $F$ & $P$ & d.f. & $F$ & $P$ & d.f. & $F$ & $P$ & d.f. & $F$ & $P$ & d.f. & $F$ & $P$ & d.f. & $F$ & $P$ \\
\hline $\mathrm{C}: \mathrm{N}$ & 2 & 26.85 & $<0.001$ & 3 & 2.04 & 0.12 & 1 & 41.88 & $<0.001$ & 6 & 2.91 & 0.02 & 3 & 0.61 & 0.61 & 6 & 2.07 & 0.07 \\
\hline $\mathrm{N}: \mathrm{P}$ & 2 & 53.15 & $<0.001$ & 3 & 27.02 & $<0.001$ & 1 & 0.00 & 0.99 & 6 & 7.18 & $<0.001$ & 3 & 1.01 & 0.40 & 6 & 1.35 & 0.25 \\
\hline $\mathrm{C}: \mathrm{P}$ & 2 & 104.03 & $<0.001$ & 3 & 24.27 & $<0.001$ & 1 & 23.47 & $<0.001$ & 6 & 7.18 & $<0.001$ & 3 & 1.90 & 0.14 & 6 & 1.19 & 0.33 \\
\hline
\end{tabular}




\section{Table 3(on next page)}

Correlations among soil $\mathrm{C}: \mathrm{N}: \mathrm{P}$ stoichiometric ratios and plant community attributes in 2018

Note: NS_Not significant; ${ }_{-}^{*} P<0.05 ;{ }^{* *} P<0.001$. 


\begin{tabular}{llll}
\hline Variables & $\mathrm{C}: \mathrm{N}$ & $\mathrm{N}: \mathrm{P}$ & $\mathrm{C}: \mathrm{P}$ \\
\hline Tree biomass & $-0.002^{\mathrm{NS}}$ & $-0.887^{* *}$ & $-0.833^{* *}$ \\
Understory plant biomass & $-0.348^{\mathrm{NS}}$ & $0.894^{* *}$ & $0.516^{\mathrm{NS}}$ \\
Litter stock & $0.862^{* *}$ & $-0.212^{\mathrm{NS}}$ & $-0.825^{* *}$ \\
Total aboveground biomass & $-0.006^{\mathrm{NS}}$ & $-0.875^{* *}$ & $-0.680^{*}$ \\
Tree biomass/Total aboveground biomass & $0.371^{\mathrm{NS}}$ & $-0.954^{* *}$ & $0.563^{\mathrm{NS}}$ \\
Understory plant biomass/Total aboveground biomass & $-0.502^{\mathrm{NS}}$ & $0.910^{* *}$ & $-0.044^{\mathrm{NS}}$ \\
Fine root biomass & $-.632^{*}$ & $-0.591^{*}$ \\
Litter carbon & $-0.595^{*}$ & $0.292^{\mathrm{NS}}$ & $0.356^{\mathrm{NS}}$ \\
Litter nitrogen & $0.149^{\mathrm{NS}}$ & $-0.279^{\mathrm{NS}}$ & $-0.535^{\mathrm{NS}}$ \\
Litter phosphorus & $0.03^{\mathrm{NS}}$ & $0.271^{\mathrm{NS}}$ & $-0.610^{*}$ \\
Litter C:N & $-0.339^{\mathrm{NS}}$ & $-0.587^{*}$ & $0.561^{\mathrm{NS}}$ \\
Litter N:P & $0.063^{\mathrm{NS}}$ & $-0.434^{\mathrm{NS}}$ & $0.143^{\mathrm{NS}}$ \\
Litter C:P & $-0.455^{\mathrm{NS}}$ & $0.546^{\mathrm{NS}}$ & $0.833^{* *}$ \\
Richness index & $-0.129^{\mathrm{NS}}$ & $0.423^{\mathrm{NS}}$ & $0.878^{* *}$ \\
Margalef index & $0.054^{\mathrm{NS}}$ & $0.967^{* *}$ & $0.906^{* *}$ \\
Shannon-Wiever index & $0.193^{\mathrm{NS}}$ & $0.902^{* *}$ & $-0.876^{* *}$ \\
Simpson index & $-0.35^{\mathrm{NS}}$ & $0.851^{* *}$ & $-0.730^{* *}$ \\
Pielou index & $0.42^{\mathrm{NS}}$ & $0.670^{*}$ & $0.860^{* *}$ \\
\hline
\end{tabular}




\section{Table 4 (on next page)}

The different plantations component of biomass in this study area

Note: TB_Tree biomass; UPB_Understory plant biomass; LS_Litter stock; TAB_Total aboveground biomass; TB:TAB_Tree biomass/Total aboveground biomass;

UPB:TAB_Understory plants biomass/Total aboveground biomass ; Lower-case letters indicate significant differences between tree species $(P<0.05)$. 


\begin{tabular}{|c|c|c|c|c|c|c|}
\hline Species identity & TB $\left(\mathrm{t} \cdot \mathrm{ha}^{-1}\right)$ & $\mathrm{UPB}\left(\mathrm{t} \cdot \mathrm{ha}^{-1}\right)$ & $\operatorname{LS}\left(\mathrm{t} \cdot \mathrm{ha}^{-1}\right)$ & $\operatorname{TAB}\left(\mathrm{t} \cdot \mathrm{ha}^{-1}\right)$ & TB:TAB & UPB:TAB \\
\hline LAR & $91.63 \pm 13.35 b c$ & $0.29 \pm 0.095 \mathrm{~b}$ & $8.35 \pm 0.41 \mathrm{a}$ & $100.27 \pm 13.68 b c$ & $0.91 \pm 0.010 \mathrm{c}$ & $0.005 \pm 0.0004 b$ \\
\hline PT & $157.16 \pm 37.57 \mathrm{ab}$ & $0.26 \pm 0.037 \mathrm{~b}$ & $7.72 \pm 0.44 \mathrm{a}$ & $165.13 \pm 38.03 \mathrm{ab}$ & $0.95 \pm 0.012 b$ & $0.003 \pm 0.0009 \mathrm{~b}$ \\
\hline $\mathrm{CJ}$ & $210.65 \pm 8.20 \mathrm{a}$ & $0.25 \pm 0.147 \mathrm{~b}$ & $3.94 \pm 0.17 \mathrm{~b}$ & $214.84 \pm 8.29 \mathrm{a}$ & $0.98 \pm 0.001 \mathrm{a}$ & $0.002 \pm 0.0006 \mathrm{~b}$ \\
\hline S & $29.26 \pm 2.53 c$ & $10.69 \pm 1.308 \mathrm{a}$ & $3.87 \pm 0.89 \mathrm{~b}$ & $43.81 \pm 3.41 \mathrm{c}$ & $0.67 \pm 0.012 \mathrm{~d}$ & $0.075 \pm 0.0061 \mathrm{a}$ \\
\hline
\end{tabular}

